\title{
PENINGKATAN KEMAMPUAN GURU DALAM PEMBELAJARAN TUNARUNGU MELALUI PELATIHAN CONTEXTUAL LEARNING DI SEKOLAH INKLUSIF
}

\author{
Murni Winarsih \\ e-mail: winarsih.murni@yahoo.com \\ Pendidikan Luar Biasa FIP UNJ
}

\begin{abstract}
Abstrak: Tujuan penelitian ini menghasilkan produk paket pelatihan berbasis contextual learning bagi guru untuk pembelajaran tunarungu di sekolah inklusif. Latar belakang pengembangan paket pelatihan ini adalah belum tersedia paket pelatihan tentang pembelajaran tunarungu dan kebutuhan guru yang belum memiliki kemampuan tentang pembelajaran tunarungu di sekolah inklusif. Penelitian ini dilakukan Februari 2012 sampai bulan Juli 2013. Metode yang digunakan Research and Development Borg dan Gall, dan untuk pengembangan modul pelatihan digunakan Model Pengembangan Instruksional (MPI). Hasil penelitian ini adalah paket pelatihan berbasis contextual learning untuk guru dalam pembelajaran siswa tunarungu, yang terdiri dari desain pelatihan, pedoman penggunaan untuk instruktur dan untuk peserta, 4 modul pelatihan dan CD materi pelatihan yang telah teruji efektivitas, efisiensi dan kelayakannya. Penelitian ini menghasilkan beberapa saran.
\end{abstract}

Kata kunci: paket pelatihan, sekolah inklusif, pembelajaran tunarungu, contextual learning.

\section{IMPROVING THE TEACHER'S COMPETENCE IN TEACHING THE HEARING IMPARED STUDENTS THROUGH CONTEXTUAL IN INCLUSIVE SCHOOL}

\begin{abstract}
This study aimed at producing a set of contextual-learning based training package for teachers of inclusive school to teach hearing impaired students. The absence of the instructional packages for hearing impaired students and the lack of the teachers' competence at inclusive school were underlied the need for this research. Borg and Gall's Research and Development methods were employed in this study and Instructional Development Model (MPI) was applied to develop the package. At the end, the research produced a set of contextual-learning-based training package for teachers to teach hearing impaired students, it included the design of training, user's guide for instructure and participant, 4 modules with soft-copy (CD) of training materials that had been tested for the effectivity, efficiency, and feasibility. Besides, the research provided a number some of recommendation.
\end{abstract}

Keywords: a training package, inclusive school, teaching the hearing impairment, contextual learning

\section{PENDAHULUAN}

Pendidikan inklusif dalam pelaksanaannya tidak sekedar memasukkan siswa berkebutuhan khusus ke dalam sistem pendidikan formal pada umumnya. Siswa tunarungu merupakan salah satu dari beberapa jenis siswa berkebutuhan khusus yang dapat masuk ke dalam sistem pendidikan inklusif. Siswa tunarungu adalah siswa yang mengalami hambatan pendengaran, mulai dari gradasi ringan sampai sangat berat. Karakteristik siswa tunarungu berbeda dengan siswa pada umumnya, siswa tunarungu memiliki hambatan pendengaran sehingga berdampak dalam kemampuan bahasa dan komunikasi.

Siswa tunarungu yang ada di sekolah inklusif pada umumnya memiliki intelegensi rata-rata bahkan ada yang di atas rata-rata. Hal ini menunjukkan bahwa siswa tunarungu mampu mengikuti pembelajaran apabila didukung dengan kompetensi guru di sekolah inklusif yang mampu memahami karakteristik dan mampu menerapkan prinsip-prinsip khusus dalam pembelajaran kepada siswa tunarungu. Berdasarkan wawancara dan observasi dalam penelitian pendahuluan kepada 5 orang guru di sekolah inklusif, diperoleh temuan bahwa guru belum memiliki kemampuan tentang pendidikan inklusif, guru belum memiliki kemampuan tentang karakteristik siswa tunarungu, guru belum memiliki kemampuan dalam membuat program pembelajaran individual untuk siswa tunarungu, guru belum menggunakan prinsip-prinsip dan strategi pembelajaran untuk siswa tunarungu dan guru belum mampu melakukan komunikasi yang efektif dengan 
siswa tunarungu dalam proses pembelajaran.

Ketidakmampuan guru di sekolah inklusif dalam melakukan pembelajaran kepada siswa tunarungu tentunya akan berdampak terhadap kualitas hasil belajarnya. Untuk itu guru di sekolah inklusif harus diberikan bekal pengetahuan dan keterampilan tentang karakteristik siswa tunarungu, cara-cara berkomunikasi dengan siswa tunarungu, cara membuat program pembelajaran individual (PPI) bagi siswa tunarungu, media dan metode serta prinsip-prinsip pembelajaran yang sesuai dengan karakteristik siswa tunarungu.

Penelitian yang relevan juga didapatkan dari hasil penelitian yang dilakukan oleh Ecaterina Maria Unianu di Rumania pada tahun 2011 mengenai sikap guru dalam kaitannya dengan pendidikan inklusif. Hasil penelitian mengungkapkan bahwa sikap guru dalam pelaksanaan pendidikan inklusif dapat dibentuk dan dikembangkan melalui program pelatihan. Keterampilan pelatihan yang diberikan mencakup struktur kurikulum, bantuan lebih untuk mendukung guru, waktu yang lebih dalam menyiapkan aktivitas pendidikan, mengurangi jumlah siswa di dalam kelas, membuat dan mengembangkan kesempatan untuk bekerjasama interaktif antara guru, siswa, guru pendukung, dan orangtua.

Perubahan kurikulum mungkin dapat dibuat secara paralel dengan pelatihan yang tepat untuk guru tentang pengetahuan mengenai pendidikan inklusif dan prinsip-prinsipnya. Kesulitan-kesulitan yang terjadi dalam melaksanakan pendidikan inklusif, dan perlu dikembangkan sistem pendidikan tepat untuk mengatasi semua karakteristik-karakteristik dan perbedaan individual yang ada pada siswa di sekolah inklusif.

Begitupula untuk mengatasi permasalahan guru di Indonesia dalam pelaksanaan pendidikan inklusif, diperlukan bekal pengetahuan dan keterampilan yang harus dikemas dalam paket pelatihan secara khusus agar mampu mengakomodasi kebutuhan guru di sekolah inklusif. Untuk itu peneliti mengembangkan paket pelatihan berbasis contextual learning bagi guru untuk pembelajaran tunarungu di sekolah penyelenggara pendidikan inklusif. Contextual learning dipilih karena pelatihan-pelatihan yang ada selama ini hanya dengan metode ceramah, sehingga tidak memberikan keterampilan khusus kepada pesertanya dan mudah terlupakan serta kurang bermakna. Melalui contextual learning diharapkan guru-guru di sekolah inklusif memiliki pengetahuan dan keterampilan yang dapat mendukung proses pembelajaran kepada siswa tunarungu.

Artikel ini membahas hasil penelitian tentang peningkatan kemampuan guru di sekolah inklusif dalam pembelajaran tunarungu melalui pelatihan berbasis contextual learning.

\section{METODE PENELITIAN}

Penelitian ini menggunakan metode Research and Development Borg and Gall. Diawali dengan penelitian pendahuluan yang pengumpulan datanya dilakukan dengan cara observasi untuk melihat bagaimana kemampuan guru dalam melaksanaan pembelajaran kepada siswa tunarungu di sekolah inklusif. Sebagai penguat hasil observasi dilakukan wawancara terhadap guru di sekolah inklusif dari jenjang pendidikan dasar hingga pendidikan menengah atas. Wawancara dilakukan kepada 5 orang guru yang di dalam kelasnya terdapat siswa tunarungu terkait dengan pendidikan inklusif, karakteristik ABK, Program Pembelajaran Individual (PPI) dan strategi pembelajaran, serta komunikasi siswa tunarungu di kelas inklusif. Berdasarkan analisis kebutuhan dari temuan penelitian pendahuluan lalu dianalisis, kemudian dikembangkan paket pelatihan berbasis contextual learning. Paket pelatihan ini dibuat dalam bentuk modul, yang desain pembelajarannya mengikuti langkah-langkah dalam Model Pengembangan Instruksional (MPI).

Penelitian ini dilakukan selama 1 tahun 5 bulan, yakni mulai bulan Februari 2012 sampai bulan Juli 2013. Untuk mengetahui efektifitas produk dilakukan uji ahli yaitu ahli bahasa, ahli desain instruksional, ahli materi ketunarunguan, uji one to one kepada 3 orang guru yang mengajar siswa tunarungu di sekolah inklusif, uji kelompok kecil kepada 11 guru di sekolah inklusif yang di kelasnya terdapat siswa tunarungu, dan uji lapangan selama 3 hari kepada 27 guru di sekolah inklusif yang terdapat siswa tunarungu, yang ada pada sekolah dasar, sekolah menengah pertama dan sekolah menengah atas.

\section{HASIL DAN PEMBAHASAN}

Penelitian ini menemukan, guru belum mampu melakukan pembelajaran sesuai dengan karakteristik siswa tunarungu, seperti memperhatikan keterarahwajahan, keterarahsuaraan, tidak membelakangi siswa saat berbicara, artikulasi harus jelas serta guru belum menggunakan media visual yang dapat membantu proses pembelajaran tunarungu di sekolah inklusif.

Temuan lain yaitu guru di sekolah inklusif selama ini belum pernah mengikuti pelatihan yang terkait dengan pendidikan inklusif maupun pelatihan 
yang khusus membahas tentang pembelajaran tunarungu, dikarenakan sampai saat ini belum adanya paket pelatihan tentang pembelajaran tunarungu. Pelatihan yang ada saat ini belum mengandung unsur praktik, dan tidak mengakomodasi kebutuhan guruguru di sekolah inklusif.

Hasil pengembangan dari penelitian ini berupa "Paket Pelatihan Berbasis Contextual learning Bagi Guru Untuk Pembelajaran Tunarungu di Sekolah Penyelenggara Pendidikan Inklusif" sebagai nama produk. Sedangkan Isi paket pelatihan berbasis Contextual learning ini meliputi: (1) desain pelatihan; (2) buku pedoman untuk instruktur; yang berisi latar belakang pelatihan, tujuan pelatihan, sekilas mengenai pelatihan berbasis contextual learning, jadwal kegiatan pelatihan, petunjuk tahapan kegiatan pelatihan, kurikulum pelatihan, silabus, materi pelatihan; (3) buku pedoman untuk peserta; yang berisi latar belakang, deskrispsi modul pelatihan, sasaran pelatihan, tujuan modul pelatihan, metode pelatihan, materi pelatihan, evaluasi pelatihan, instruktur pelatihan, waktu pelatihan, petunjuk belajar dan soal evaluasi pre-test dan post-test; (4) materi pelatihan yang terdiri dari modul 1 sampai modul 4; dan (5) CD materi pelatihan.

Produk paket pelatihan berbasis Contextual learning bagi guru untuk pembelajaran tunarungu ini secara karakteristiknya adalah sebagai berikut: (1) paket pelatihan berbasis contextual learning dirancang dan dikembangkan untuk tiga hari pelatihan, dengan mengacu pada karakteristik kemampuan guru di sekolah inklusif terkait dengan pembelajaran kepada siswa tunarungu; (2) paket pelatihan berbasis contextual learning didesain dan dikembangkan dengan pendekatan sistem yang mengacu pada Model Pengembangan Instruksional (MPI); (3) paket pelatihan ini dirancang berdasarkan analisis kebutuhan dan dikemas dalam bentuk pembelajaran yang aktif, dengan mengkolaborasikan beberapa metode, strategi pembelajaran dengan pendekatan contextual learning; (4) paket pelatihan ini dirancang dan dikembangkan mengacu pada keterampilan khusus yaitu mampu melakukan pembelajaran untuk siswa tunarungu di sekolah inklusif yang harus dicapai oleh peserta pelatihan setelah mengikuti pelatihan; (5) sasaran pelatihan ini adalah guru yang mengajar siswa tunarungu di sekolah penyelenggara pendidikan inklusif dengan jumlah maksimal 30 orang; (6) paket pelatihan berbasis contextual learning ini dirancang dan dikembangkan berdasarkan karakteristik tugas-tugas perkembangan orang dewasa (usia 30 - 60 tahun); (7) media pembelajaran yang digunakan dalam paket pelatihan berbasis contextual learning ini berupa media presentasi power point dengan menggunakan LCD proyektor; (8) metode pembelajaran dalam paket pelatihan berbasis contextual learning ini adalah dengan memvariasikan beberapa metode; (9) bahan belajar yang dikembangkan dalam paket pelatihan ini berupa modul pelatihan yang digunakan saat pelatihan berlangsung, yang dirancang dan dikembangkan secara sistematis, dilengkapi dengan tugas mandiri dan studi kasus serta soal-soal latihan; (10) paket pelatihan berbasis contextual learning ini dilengkapi dengan pedoman untuk instruktur dan pedoman untuk peserta; dan (11) dalam pelaksanaan paket pelatihan ini, evaluasi dilakukan secara proses, baik sebelum pelatihan, saat pelatihan berlangsung dan setelah pelatihan.

Pengembangan paket pelatihan berbasis contextual learning bagi guru untuk pembelajaran tunarungu di sekolah penyelenggara pendidikan inklusif, meliputi tiga bentuk yaitu; (1) model konseptual merupakan perwujudan dari konseptualisasi teoriteori dan prinsip-prinsip yang terintegrasi sedemikian rupa membentuk paket pelatihan berbasis contextual learning bagi guru untuk pembelajaran tunarungu di sekolah penyelenggara pendidikan inklusif; (2) model prosedural merupakan perwujudan tahapantahapan pembentukan paket pelatihan berbasis contextual learning; (3) model fisikal adalah hasil nyata berupa desain pelatihan, dan (4) modul pelatihan yang terdiri dari pendidikan inklusif; mengenal anak berkebutuhan khusus; PPI dan program pembelajaran di sekolah inklusif; pembelajaran tunarungu di sekolah penyelenggara pendidikan inklusif, dan pedoman penggunaan serta di lengkapi dengan CD paket pelatihan.

Paket pelatihan berbasis contextual leaning bagi guru untuk pembelajaran tunarungu di sekolah penyelenggara pendidikan inklusif memiliki beberapa kelebihan dan kelemahan, yaitu:

\section{Kelebihan}

a. Modul untuk peserta dibuat dalam ukuran B5 dan bentuk tidak terlalu tebal sehingga memudahkan untuk dibawa, serta meminimalkan upaya penggandaan yang tidak resmi.

b. Lay-out modul pada bagian cover dibuat dengan warna dan ilustrasi yang berbeda sehingga memberikan kemudahan bagi pengguna modul dalam membedakan antara modul satu dengan modul yang lainnya.

c. Modul dibuat dalam satuan yang terpisah dengan menggunakan bahasa yang sederhana dan dilengkapi dengan daftar istilah, sehingga 
memudahkan peserta pelatihan untuk menguasai materi dalam setiap modul.

d. Materi dalam modul bersifat meluas, maksudnya satu konsep namun pembahasannya secara menyentuh sehingga menambah wawasan peserta pelatihan mengenai pendidikan inklusif dan pembelajaran ketunarunguan.

e. Setiap modul dilengkapi dengan tugas dan studi kasus sehingga dapat digunakan untuk memperdalam penguasaan materi.

f. Paket pelatihan ini dirancang berbasis contextual learning dengan berusaha menghadirkan kondisi nyata dalam proses pelatihan sehingga memudahkan peserta dalam menguasai keterampilan mengenai pembelajaran siswa tunarungu di sekolah penyelenggara pendidikan inklusif.

g. Pedoman modul tersedia dalam dua jenis yaitu pedoman untuk peserta dan pedoman untuk instruktur untuk memudahkan peserta memahami paket pelatihan dan untuk memudahkan instruktur dalam penyampaian materi pelatihan.

h. Paket pelatihan dilengkapi pula dengan CD yang berisi soft copy power point tiap modul sehingga dapat membantu peserta pelatihan mengingat kembali materi yang telah diberikan.

i. Pelatihan diisi oleh instruktur yang berpengalaman, mumpuni dan memiliki kompetensi pada bidang keahlian pendidikan luar biasa.

j. Paket pelatihan dikemas dalam satu wadah khusus, sehingga tidak mudah tercecer.

\section{Kelemahan}

a. Paket pelatihan ini hanya bisa diberikan oleh instruktur yang berlatar belakang pendidikan luar biasa dan berpengalaman di bidangnya.

b. Modul ini dirancang khusus untuk guru reguler yang mengajar siswa tunarungu di kelas inklusif.

c. Modul bersifat teoretis dan praktis yang saling berkaitan, untuk bisa mempraktikkan modul ini harus mempelajari teorinya terlebih dahulu.

d. Paket pelatihan ini harus dilakukan dalam setting posisi duduk peserta pelatihan berbentuk setengah lingkaran (U), jadi membutuhkan ruangan yang memadai.

Pengembangan paket pelatihan berbasis contextual learning ini merupakan upaya dalam memfasilitasi pembelajaran agar tercipta pembelajaran yang efektif, efisien dan menarik sehingga meningkatkan kinerja dalam bidang pendidikan.

\section{Pembahasan}

Berdasarkan temuan penelitian maka pembahasan hasil penelitian ini akan dijabarkan sebagai berikut:

Pertama, guru di sekolah penyelenggara pendidikan inklusif belum memiliki kemampuan dalam mengenali karakteristik ABK, belum membuat program pembelajaran individual bagi tunarungu, belum menggunakan metode dan media yang sesuai dengan kebutuhan siswa tunarungu, belum menggunakan pendekatan khusus yang mampu membantu tunarungu dalam berkomunikasi, guru belum pernah mengikuti pelatihan tentang pembelajaran tunarungu, serta belum adanya bahan belajar untuk guru yang dapat membantu dalam proses pembelajaran kepada siswa tunarungu.

Ketidakmampuan guru tersebut dikarenakan guru tidak memiliki latar belakang pendidikan luar biasa, dan guru reguler yang menangani ABK juga tidak dibekali dengan pengetahuan dan keterampilan khusus, serta kurikulum di LPTK belum memuat tentang materi pendidikan inklusif dalam mata kuliah tersendiri ataupun masuk dalam mata kuliah dasar kependidikan (MKDK) sebagai bekal calon guru yang akan mengajar di sekolah reguler. Berdasarkan pengalaman peneliti bahwa lulusan yang berasal dari jurusan pendidikan luar biasa yang sudah dibekali pengetahuan dan keterampilan tentang $\mathrm{ABK}$, masih mengalami kendala dalam memberikan pembelajaran kepada ABK di SLB, lalu bagaimana dengan guruguru reguler yang menangani $\mathrm{ABK}$ di sekolah inklusif yang sama sekali tidak mendapatkan pengetahuan dan keterampilan dalam menangani ABK? Tentunya ini menjadi pekerjaan rumah bagi pemerintah terutama kementerian pendidikan dan kebudayaan serta para penyelenggara pendidikan inklusif dalam meningkatkan kemampuan guru.

Ketidakmampuan guru dalam melakukan pembelajaran berakibat kepada hasil belajar siswa tunarungu yang rendah dan tidak optimal. Untuk mengatasi permasalahan guru di sekolah inklusif perlu dikembangkan paket pelatihan berbasis contextual learning. Pelatihan yang diselengggarakan hendaknya sesuai dengan kebutuhan dan karakteristik guru. Hal ini sesuai dengan konsep bahwa pelatihan adalah usaha yang dilakukan untuk mengembangkan sumber daya agar tercipta pengetahuan dan keterampilan dalam rangka peningkatan kualitas pembelajaran.

Selama ini belum ada pelatihan yang diselenggarakan untuk guru di sekolah penyelenggara pendidikan inklusif yang didukung dengan bahan belajar yang sesuai dengan karakteristik guru, sehingga pelatihan yang ada belum sepenuhnya bermakna dalam melakukan pembelajaran kepada siswa tunarungu. Peneliti juga memiliki keyakinan 
bahwa paket pelatihan ini jika diberikan kepada calon guru atau para mahasiswa yang berada di LPTK, tentunya dapat membantu dalam mendalami materi pendidikan inklusif dan $\mathrm{ABK}$, selain didukung dengan teori, paket pelatihan ini juga mengutamakan praktik yang di desain secara khusus agar mudah dipahami dan mudah diaplikasikan. Para mahasiswa kependidikan saat ini kurang dibekali dengan praktik, juga dengan ditiadakannya pratik keja lapangan (PPL) dalam kurikulum, melalui paket pelatihan berbasis contextual learning ini sangat terbantu dan memberikan wawasan serta pengetahuan yang dapat diaplikasikan dikemudian hari.

Bahan belajar yang dikemas dalam satu paket selama inipun belum pernah ada, sehingga apabila dipelajari secara berkesinambungan akan membentuk satu konsep pengetahuan secara utuh, sehingga memberi kemudahan kepada mahasiswa dan guru untuk memahami tentang pelaksanaan pembelajaran siswa tunarungu di sekolah inklusif.

Pelatihan berbasis contextual learning ini ternyata berhasil mengatasi permasalahan guru dalam pembelajaran kepada siswa tunarungu. Keberhasilan ini dikarenakan pelatihan kontekstual sesuai digunakan untuk pembelajaran bagi orang dewasa serta memiliki kemudahan dalam penyerapan makna dan nilai-nilai yang didapat selama kegiatan belajar. Melalui contextual learning pelatihan yang dilakukan relevan atau memiliki kaitan langsung dengan kenyataan di lapangan. Hal ini terlihat dalam proses pelaksanaan kegiatan pelatihan, mulai dari penggunaan modul pelatihan, bentuk tata ruang pelatihan yang disesuaikan dengan kondisi pembelajaran bagi siswa tunarungu di sekolah penyelenggara pendidikan inklusif, dan pelatihan yang dilakukan lebih banyak unsur praktik dibandingkan ceramahnya. Sehingga melalui pelatihan berbasis contextual learning, peningkatan kualitas guru setelah mengikuti kegiatan pelatihan dapat benar-benar terealisasi.

Keberhasilan paket pelatihan berbasis contextual learning ini hendaknya menjadi perhatian khusus pemerintah melalui kementerian pendidikan dan kebudayaan sebagai lembaga tertinggi yang menangani kualitas guru di seluruh Indonesia, bekerjasama dengan dinas pendidikan dan badan diklat, dalam merancang pelatihan untuk guru seharusnya mengedepankan unsur-unsur praktik yang memudahkan guru dalam mengingat kembali materi pelatihan. Pelatihan yang dilakukan hendaknya dirancang sesuai dengan kebutuhan guru di lapangan, tidak sekedar mengejar target dan proyek saja, sehingga pelatihan yang diselenggarakan mencapai tujuan yang diharapkan.

LPTK sebagai lembaga penghasil guru hendaknya mengkaji kembali kurikulum yang ada saat ini, memikirkan kembali mata kuliah PPL yang telah dihapuskan, harus dimunculkan lagi atau diganti dengan bentuk lain yang mampu memberikan bekal praktik untuk para mahasiswa sebagai calon guru agar lebih terampil dalam melakukan pembelajaran. LPTK diharapkan bekerjasama dengan penyelenggara pendidikan untuk melakukan perubahan dan perbaikan mata kuliah yang ada sesuai dengan analisis kebutuhan di lapangan. Untuk jurusan pendidikan luar biasa (PLB) hendaknya bekerjasama dengan jurusan lainnya dalam fakultas ilmu pendidikan untuk memformulasikan mata kuliah yang terkait dengan pembelajaran siswa berkebutuhan khusus dapat diberikan kepada seluruh mahasiswa di fakultas yang terkait. Dengan demikian tidak terjadi kesenjangan antara teori yang dipelajari di perguruan tinggi dengan praktik yang terjadi di sekolah.

Untuk mengatasi kelemahan dalam paket pelatihan ini, hendaknya dalam proses pelaksanaan pelatihan berbasis contextual learning ini pihak penyelenggara bekerjasama dengan jurusan pendidikan luar biasa, yang secara keilmuan memiliki keahlian terkait dengan siswa berkebutuhan khusus dan pelaksanan pendidikan inklusif. Sehingga pelatihan yang diselenggarakan dapat berhasil sesuai dengan tujuan yang telah ditentukan.

\section{PENUTUP}

\section{Kesimpulan}

Kesimpulan dalam penelitian ini adalah: pertama, bahwa guru di sekolah penyelenggara pendidikan inklusif belum memiliki kemampuan dalam pembelajaran kepada siswa tunarungu. Kedua, untuk mengatasi permasalahan guru tersebut dikembangkanlah paket pelatihan, yang terdiri dari tiga model yaitu: model konseptual, model prosedural dan model fisikal. Ketiga, hasil uji coba lapangan menunjukkan bahwa pengembangan paket pelatihan berbasis contextual learning bagi guru untuk pembelajaran tunarungu di sekolah penyelenggara pendidikan inklusif ini efektif, efisien dan menarik sebagai paket pelatihan bagi guru reguler di sekolah penyelenggara pendidikan inklusif. Sehingga dapat disimpulkan bahwa produk dari hasil penelitian ini yang berupa paket pelatihan pembelajaran tunarungu bagi guru di sekolah penyelenggara pendidikan inklusif dikatakan valid dan dapat digunakan untuk meningkatkan kompetensi guru dalam pembelajaran kepada siswa tunarungu 
di sekolah inklusif. Sehingga pengembangan paket pelatihan berbasis contextual learning ini dapat mengatasi permasalahan guru yang ada saat ini di sekolah penyelenggara pendidikan inklusif yaitu dalam pembelajaran tunarungu.

Hasil penelitian ini berimplikasi terhadap kurikulum di LPTK yang perlu dikaji kembali sesuai dengan kebutuhan di lapangan. Diperlukan kerjasama yang berkesinambungan antara kementerian pendidikan dan kebudayaan, dinas pendidikan, sekolah dan LPTK dalam melaksanakan pendidikan inklusif di sekolah, dengan selalu meningkatkan kemampuan guru melalui pelatihan-pelatihan yang berkualitas. Pembinaan langsung kepada sekolah-sekolah inklusif hendaknya dilakukan terus menerus oleh dinas pendidikan dan kebudayaan serta pihak terkait, dengan memberikan fasilitas pembelajaran kepada siswa dan guru sehingga pembelajaran yang dihasilkan dapat berkualitas.

\section{DAFTAR PUSTAKA}

Borg, W.R. \& Gall, M.D. (2007). Educational research: An introduction. Edisi ke-8. New York: Longman, Inc.

Gagne \& Briggs, L.J. (1984). Principles of instructional design. New York: Holt Rinehat and Winston Inc.
Gustafson, K.L., \& Branch, R.B. (2002). Survey of instructional development model. New York: Eric Clearinghouse on Information \& Techology Syracuse University.

Johnson, E.B. (2007). Contextual teaching and learning. Bandung: Mizan Learning Center.

Johnsen H.B. \& Skjorten, D.M. (2003). Menuju inklusi buku 1 pendidikan kebutuhan khusus: Sebuah pengantar. Bandung: Program Pascasarjana Universitas Pendidikan Indonesia.

Miarso, Y. (2009). Menyemai benih Teknologi Pendidikan. Jakarta: Kencana.

Purwanto, A.R. \& Lasmono, S. (2007). Pengembangan modul. Jakarta: Departemen Pendidikan Nasional, Pusat Teknologi Informasi dan Komunikasi Pendidikan.

Sitepu, B.P. (2006). Penyusunan buku pelajaran. Jakarta: Verbum Publishing.

Sitepu, B.P. (2012). Penulisan buku teks pelajaran. Bandung: Rosda Karya.

Suparman, A. (2010). Desain instruksional. Jakarta: Universitas Terbuka.

Unianu, E.M. “Teacher's attitudes towards inclusive education", Journal of Social and Behavioal Science, volume 2011.

Walter, D., Carey, L. \& Carey, J.O. The systematic design of instruction. Boston: Pearson, 2005. 